\title{
Virulence of the Pseudomonas fluorescens clinical strain MFN1032 towards Dictyostelium discoideum and macrophages in relation with type III secretion system
}

Daniel Sperandio, Victorien Decoin, Xavier Latour, Lily Mijouin, Mélanie Hillion, Marc G J Feuilloley, Nicole Orange and Annabelle Merieau*

\begin{abstract}
Background: Pseudomonas fluorescens biovar I MFN1032 is a clinical isolate able to grow at $37^{\circ} \mathrm{C}$. This strain displays secretion-mediated hemolytic activity involving phospholipase $\mathrm{C}$ and cyclolipopeptides, and a cell-associated hemolytic activity distinct from the secreted hemolytic activity. Cell-associated hemolysis is independent of biosurfactant production and remains in a gacA mutant. Disruption of the hrpU-like operon (the basal part of type III secretion system from rhizospheric strains) suppresses this activity. We hypothesized that this phenotype could reflect evolution of an ancestral mechanism involved in the survival of this species in its natural niche. In this study, we evaluated the hrpU-like operon's contribution to other virulence mechanisms using a panel of Pseudomonas strains from various sources.

Results: We found that MFN1032 inhibited the growth of the amoebae Dictyostelium discoideum and that this inhibition involved the hrpU-like operon and was absent in a gacA mutant. MFN1032 was capable of causing macrophage lysis, if the hrpU-like operon was intact, and this cytotoxicity remained in a gacA mutant. Cell-associated hemolytic activity and macrophage necrosis were found in other $P$. fluorescens clinical isolates, but not in biocontrol P. fluorescens strains harbouring hrpU-like operon. The growth of Dictyostelium discoideum was inhibited to a different extent by P. fluorescens strains without correlation between this inhibition and hrpU-like operon sequences.

Conclusions: In P. fluorescens MFN1032, the basal part of type III secretion system plays a role in D. discoideum growth inhibition and macrophage necrosis. The inhibition of D. discoideum growth is dependent on the GacS/ GacA system, while cell-associated hemolytic activity and macrophage lysis are not. Virulence against eukaryotic cells based on the hrpU-like operon may be more than just a stochastic evolution of a conserved system dedicated to survival in competition with natural predators such as amoebae. It may also mean that there are some important modifications of other type III secretion system components, which remain unknown. Cell-associated hemolysis might be a good indicator of the virulence of Pseudomonas fluorescens strain.
\end{abstract}

Keywords: Pseudomonas fluorescens clinical strains, Type III secretion system, Dictyostelium discoideum, Macrophage necrosis, Cell-associated hemolytic activity

\footnotetext{
* Correspondence: annabelle.merieau@univ-rouen.fr

LMSM, Laboratoire de Microbiologie Signaux et Micro-Environnement, EA

4312, Université de Rouen, 55 rue Saint Germain, Evreux 27000, France
} 


\section{Background}

Pseudomonas fluorescens is a highly heterogeneous species of $\gamma$ Proteobacteria [1,2]. Saprophytic members of this species are found in large numbers in all of the major natural environments and also form associations with plants [3-5]. Surprisingly, P. fluorescens includes some strains suspected to be opportunistic human pathogens [6,7]. Recently, and despite its psychrotrophy (optimal growth temperature range between $25-30^{\circ} \mathrm{C}$ ) [8], several studies highlighted the infectious potential of some Pseudomonas fluorescens clinical strains [9-11]. MFN1032 is a clinical strain, identified as belonging to biovar I of $P$. fluorescens species, which was isolated from a patient with a lung infection and is able to grow at $37^{\circ} \mathrm{C}$ [11]. We previously described that MFN1032 cells induce necrosis and apoptosis in rat glial cells at this temperature. This strain adheres to intestinal epithelial cells where it induces cytotoxic effects and proinflammatory reactions [12]. MFN1032 displays secretion-mediated hemolytic activity involving phospholipase $C$ and cyclolipopeptides [13]. This activity is positively regulated by the two-component system GacS/ GacA and is subject to phase variation [9,14]. MFN1032 shows a cell-associated hemolytic activity distinct from the secreted hemolytic activity. The cell-associated hemolytic activity (cHA) is expressed at $37^{\circ} \mathrm{C}$ and is detected in vitro in mid log growth phase in the presence of erythrocytes. This cHA is independent of phospholipase $\mathrm{C}$ and cyclolipopeptide production and increases in a gacA mutant. GacS/GacA seems to be a negative regulator of this activity. Finally, MFN1032 harbours type III secretion system (T3SS) genes [15]. In Pseudomonas aeruginosa CHA strain, cell-associated hemolytic activity is correlated with secretion of PcrV, PopB and PopD by T3SS. This pore forming activity precedes macrophage oncosis [16]. In addition, numerous studies have reported the implication of T3SS in the infectivity of $P$. aeruginosa in Dictyostelium discoideum. $D$. discoideum is a soil amoeba that feeds on bacteria by phagocytosis $[17,18]$. It was used as a model eukaryotic cell, which mimics mammalian macrophage in how it interacts with microbes. P. aeruginosa can kill $D$. discoideum by delivering effector proteins to target cells $[19,20]$.

T3SS genes are absent from the P. fluorescens Pf0-1 and Pf5 genomes published in databases $[21,22]$ but are present in numerous plant-associated and biocontrol $P$. fluorescens strains [23-26]. Strain KD protects the cucumber from the oomycete Pythium ultimum, and its T3SS, acquired horizontally from phytopathogenic bacteria, decreases pectinase polygalacturonase activity (a key pathogenicity factor) from P. ultimum [26]. This strain does not induce a Hypersensitivity Response (HR) on tobacco leaves. In C7R12 and SBW25, two other biocontrol strains with T3SS genes, the target of T3SS has not been fully elucidated [25,27]. In P. fluorescens Q8r1-96, T3SS is different from its counterparts in SBW25 and similar to P. syringae T3SS. This strain expresses T3SS effectors capable of suppressing HR [23].

MFN1032 possesses some contrasting features of saprophytic or pathogenic Pseudomonas in regards to T3SS. MFN1032 has T3SS-like genes, hrcRST, with a high level of homology to the hrcRST genes of the hrpU operon in Pseudomonas syringae DC3000. Disruption of this hrpU-like operon in MFN1032 abolishes cellassociated hemolytic activity [15], as described for mutations in the T3SS apparatus in P. aeruginosa. Our hypothesis was that the first target of MFN1032 T3SS would probably be eukaryotic cells of the rhizosphere, such as plants or amoebae.

To test this hypothesis, we investigated the interactions of MFN1032 and other Pseudomonas strains with red blood cells, plants, amoebae and macrophages. In contrast with environmental Pseudomonas, all of the clinical strains of $P$. fluorescens tested were cytotoxic for erythrocytes through contact. MFN1032 was unable to induce HR on plants and was cytotoxic for amoebae and macrophages. Disruption of the hrpU-like operon in MFN1032 abolished these cytotoxicities that were independent of cyclolipopeptide production. GacS/GacA system seems to be a positive regulator for $D$. discoideum growth inhibition but not for cell-associated hemolysis or macrophage lysis, suggesting that these processes are not identical.

\section{Results}

P. fluorescens MFN1032 and other clinical strains have cell-associated hemolytic activity but do not induce HR on tobacco leaves

We investigated the distribution of cell-associated hemolytic activity on a panel of Pseudomonas strains. Cell-associated hemolytic activity (cHA) was measured by the technique used by Dacheux [16], adapted as described in methods. We tested $\mathrm{cHA}$ at $37^{\circ} \mathrm{C}$ for MFN1032, MFY162, MFY70 and MFY63 (clinical isolates of P. fluorescens), MF37 (P. fluorescens strain isolated from raw milk), C7R12 and SBW25 (rhizospheric $P$. fluorescens strains) and DC3000 (P. syringae plant pathogen) after growth at $28^{\circ} \mathrm{C}$ (for strain origin see Table 1).

Only clinical strains had cHA (Figure 1). MFY63 showed the highest level of cHA (80\% lysis); MFY70 and MFN1032 displayed significant cHA (70\% lysis) and MFY162 a median cHA (40\% lysis). In the case of the environmental strains tested, C7R12, SBW25, MF37 and DC3000 were not hemolytic.

The same panel of strains was tested on tobacco leaves to determine if these strains were able to induce HR. As 
Table 1 Bacterial strains used in this study, origins, growth temperatures and references

\begin{tabular}{|c|c|c|c|c|}
\hline Species & Strains & $\begin{array}{l}\text { Optimal growth } \\
\text { temperature }\left({ }^{\circ} \mathrm{C}\right)\end{array}$ & Origins & References \\
\hline \multirow[t]{14}{*}{ Pseudomonas fluorescens } & SBW25 & $28^{\circ} \mathrm{C}$ & Field grown-sugar beet & {$[25]$} \\
\hline & C7R12 & & Flax rhizosphere & {$[27]$} \\
\hline & MF37 & & Milk tank & [39] \\
\hline & MFY63 & & Clinical (urine) & [6] \\
\hline & MFY70 & & Clinical (abscess) & [6] \\
\hline & MFY162 & & Clinical (sputum) & [6] \\
\hline & MFN1032 & & Clinical (sputum) & [11] \\
\hline & MFN1030 & & MFN1032 hrpU-like operon mutant & [15] \\
\hline & MFN1030- pBBR1MCS-5 & & MFN1030 carrying pBBR1MCS-5 & This study \\
\hline & MFN1030-pBBR-rscSTU & & $\begin{array}{l}\text { MFN1030 carrying rsCSTU genes of } \\
\text { SBW25 cloned into pBBR1MCS-5 }\end{array}$ & This study \\
\hline & MFN1031 & & MFN1030 revertant & [15] \\
\hline & $\mathrm{V} 1$ & & MFN1032 spontaneous gacA mutant & [9] \\
\hline & V1gacA & & V1 carrying the gacA gene (plasmid pMP5565) & [9] \\
\hline & V3 & & MFN1032 Variant group 2 (Cyclolipopeptides -) & {$[9,14]$} \\
\hline Pseudomonas syringae & DC3000 & & Tomato & {$[40]$} \\
\hline \multirow[t]{2}{*}{ Pseudomonas aeruginosa } & $\mathrm{CHA}$ & $37^{\circ} \mathrm{C}$ & Clinical & [41] \\
\hline & PA14 & & Clinical & {$[42]$} \\
\hline Klebsiella aerogenes & $\mathrm{KA}$ & & Environmental & [43] \\
\hline
\end{tabular}

illustrated in Figure 2, HR was only detected for C7R12 and DC3000. All clinical strains i.e., MFY63, MFY70, MFY162 and MFN1032 and two environmental strains, SBW25 and MF37, were unable to induce HR.

\section{P. fluorescens MFN1032 is virulent on Dictyostelium discoideum (D. discoideum)}

As described in Figure 3A, Klebsiella aerogenes (KA) (negative control for virulence), Pseudomonas aeruginosa PA14 (positive control for virulence), and MFN1032 were tested on $D$. discoideum. On a layer of

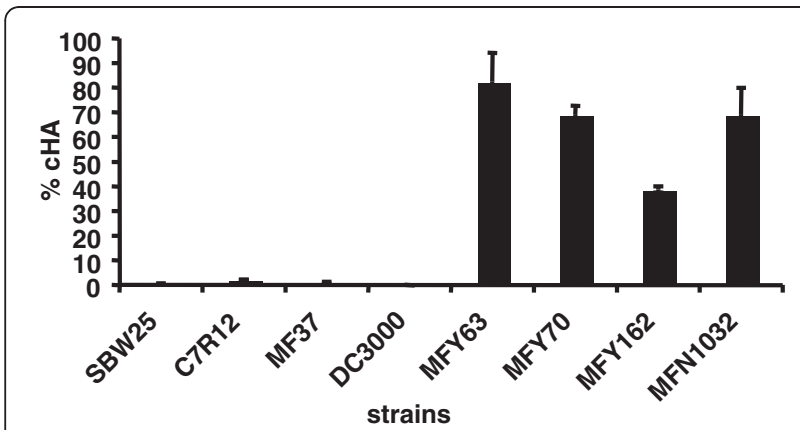

Figure 1 Cell-associated hemolytic activity (cHA). Cell-associated hemolytic activity ( $\mathrm{CHA}$ ) was measured as described in the materials and methods. Results are mean values from at least three independent experiments. Standard deviation is shown. RBCs were incubated $1 \mathrm{~h}$ at $37^{\circ} \mathrm{C}$ with MFN1032, MFY63, MFY70, MFY162, SBW25, C7R12, MF37 or DC3000 cultivated at $28^{\circ} \mathrm{C}$ (MOI of 1).
KA, about one hundred lysis plaques were observed, corresponding to the zone where actively feeding and replicating $D$. discoideum have phagocytosed the bacteria. On a layer of PA14 or MFN1032 at 10\%, no lysis plaque was detected. MFN1032 does indeed display a virulent phenotype on $D$. discoideum, either by evading D. discoideum killing, or by actively killing amoebae. Then, our panel of strains was tested on D. discoideum (Figure 3B). Two strains, C7R12 and MF37 had a complete absence of $D$. discoideum growth inhibition (100\% of D. discoideum remained). MFY63 and SBW25 were highly permissive for $D$. discoideum growth $(90 \%$ and $75 \%$ of amoebae remained, respectively). MFY70 and MFY162 permitted the replication of about half of the D. discoideum (40\% and 60\% respectively). DC3000 had a slightly virulent phenotype on $D$. discoideum (20\% of $D$. discoideum remained). In our panel, to small to be representative, $D$. discoideum growth inhibition above $50 \%$ was only observed for clinical or phytopathogenic strains of Pseudomonas.

P. fluorescens MFN1032 virulence towards D. discoideum is dependent on the hrpU-like operon and the GacS/GacA two-component system and is independent of cyclolipopeptides (CLPs).

We used a mutant strain, MFN1030, the hrpU-like operon mutant of MFN1032, to determine whether T3SS apparatus proteins are required for the MFN1032 phenotype with respect to $D$. discoideum. MFN1030 was 


\begin{tabular}{|ccc|}
\hline Strains & $\begin{array}{c}\text { Nicotania tabacum } \\
\text { cV. Leaves after 48 H }\end{array}$ & Result \\
\hline SBW25 & No HR \\
\hline C7R12 & HR \\
\hline MF37 & No HR \\
\hline DC3000 & HR \\
\hline MFY63 & No HR \\
\hline MFN1032 & No HR HR \\
\hline & \\
\hline & \\
\hline & \\
\hline
\end{tabular}

Figure 2 Plant hypersensitive response (HR) assay. P. fluorescens strains, MFN1032, MFY63, MFY70, MFY162, SBW25, C7R12, MF37 and P. syringae DC3000, were infiltrated into Nicotiana tabacum CV. leaves. The leaves were evaluated for production of HR and were photographed after $48 \mathrm{~h}$. This experiment was repeated 2 times with similar results.

permissive for $D$. discoideum growth ( $90 \%$ of $D$. discoideum remained). The revertant of MFN1030, MFN1031, inhibited D. discoideum growth.

We investigated the possible involvement of the GacS/ GacA two-component system in the regulation of this phenotype using a gacA spontaneous mutant of MFN1032, V1. V1 is defective for cyclolipopeptide (CLP) production and secreted hemolysis, but still exhibits cHA. V1 was plated on D. discoideum and allowed these amoebae to grow, as described in Figure 3B (100\% of $D$. discoideum remained). Introduction of a gacA gene in $\mathrm{V} 1$, to give the V1gacA strain, restored wild-type phenotype.

CLP biosurfactant production is positively regulated by the GacS/GacA system in numerous P.fluorescens strains $[9,28]$. Biosurfactants produced by $P$. aeruginosa have been reported to cause the lysis of $D$. discoideum [20]. To investigate the role of CLP, we took advantage of strain V3, a MFN1032 variant (described as a "group 2 variant"), which have a defect in CLP production but which have a wild type GacS/GacA $[9,14]$. V3 does not show other measurable modifications from secreted factors. V3 inhibited fully $D$. discoideum growth $(0 \%$ of amoebae remained).

$D$. discoideum growth inhibition could be due to MFN1032-induced death of Klebsiella aerogenes, which is the feeding source of the amoeba. To exclude this possibility, we counted Klebsiella aerogenes colony forming unit (CFU) after 5 days at $22^{\circ} \mathrm{C}$ in $\mathrm{SM}$ medium, either with or without the presence of MFN1032, MFN1030 or V1. In all conditions, the Klebsiella aerogenes counts were identical (approximately $10^{8} \mathrm{CFU} \cdot \mathrm{mL}^{-1}$ ).

Moreover, as described in Figure 3 C, MFN1030 as sole feeding source permitted $D$. discoideum growth in 2 days at $22^{\circ} \mathrm{C}$, while MFN1032 did not. Similar results were obtained with V1 (Data not shown).

\section{P. fluorescens MFN1032 is cytotoxic on macrophages via intracellular mechanisms}

In order to correlate $D$. discoideum growth inhibition (which mimic macrophage phagocytosis) and cytotoxicity towards macrophages, we infected cell line J774A.1 macrophages with MFN1032 (not permissive), DC3000 (slightly not permissive) and SBW25 (highly permissive) as described in Material and Methods. The strain of $P$. aeruginosa $\mathrm{CHA}$ is a clinical isolate from a patient suffering from cystic fibrosis and has been used as a positive control for macrophage lysis, monitored by LDH release [29]. This strain has a highly inducible T3SS, responsible for virulence behaviour [30]. This strain provoked full lysis of macrophages in our conditions (Figure 4). MFN1032 displayed an LDH release of 40\% whereas SBW25 and DC3000 were unable to lyse macrophages. These results showed that, in DC3000, slight virulence towards $D$. discoideum is not correlated with macrophage necrosis.

In order to determine the possible involvement of T3SS in macrophage lysis by MFN1032, we used MFN1030 (hrpU-like operon mutant) to infect J774A.1 macrophages. MFN1030 was impaired in macrophage lysis whereas MFN1031 (MFN1030 revertant) had a wild type phenotype with a $40 \% \mathrm{LDH}$ release. The gacA mutant of MFN1032, V1, had the same range of macrophage lysis as MFN1032 (Figure 4).

Confocal analysis of macrophages infected by MFN1032 was conducted to study this necrosis. Following ten minutes of infection, numerous macrophages appeared red in medium containing $\mathrm{EtBr}$, confirming a rapid necrosis (Figure 5A). Orthographic representation revealed that every dead macrophage contained MFN1032 expressing green fluorescent protein (Figure 5B). Only few live macrophages, which were not stained but perceptible by 
A

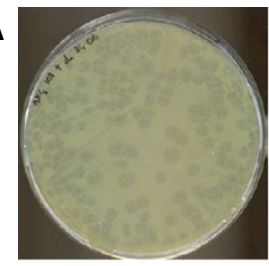

Klebsiella aerogenes (KA)

negative control

B

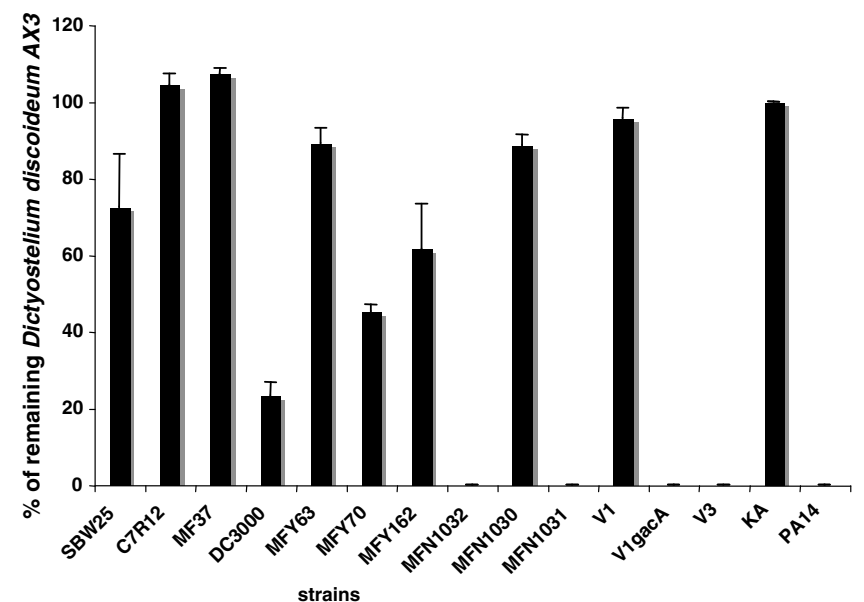

C
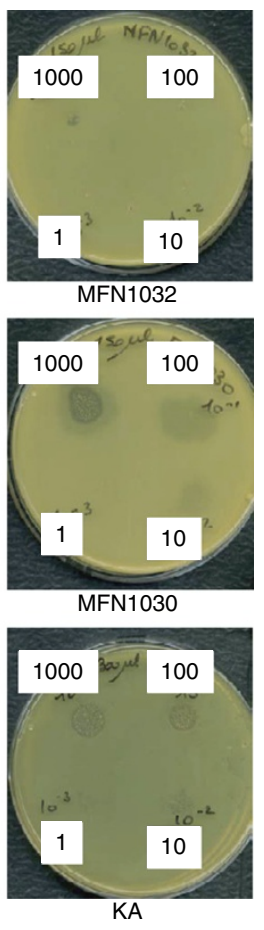

Figure 3 Virulence towards Dictyostelium discoideum. Approximately 100 D. discoideum cells were cultivated in SM-plates with the indicated proportion of Klebsiella aerogenes and Pseudomonas strains (10\%). Plates were maintained at $22^{\circ} \mathrm{C}$ for 5 days. A: Pseudomonas aeruginosa PA14 (positive control), Klebsiella aerogenes (KA, negative control) and P. fluorescens MFN1032 virulence towards D. discoideum after 5 days. B: Virulence of different Pseudomonas strains at 10\% against $D$. discoideum. These results were obtained by the ratio of the number of lysis plaques obtained with the negative control Klebsiella aerogenes (100\% of amoebae remained). Standard deviation is shown. Data are mean values from three independent experiments. C: D. discoideum growth on layer of MFN1032, MFN1030 or KA as described in the materials and methods. 1000, 100, 10 and 1 indicated number of $D$. discoideum per $\mu \mathrm{L}$.

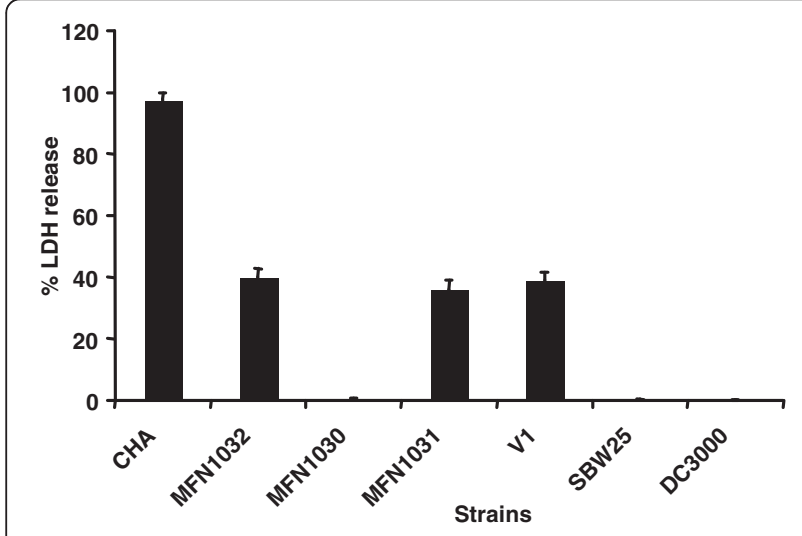

Figure 4 Cytotoxic activity on macrophage J774A. 1. J774A.1 macrophages grown in 24-well plates for $20 \mathrm{~h}$ were infected with strains grown to an $\mathrm{OD}_{580 \mathrm{~nm}}$ of 1.0-1.5 ( $\mathrm{MOl}$ of 5). The cytotoxicity was followed over a $4 \mathrm{~h}$ period by measuring LDH release using a cytotoxicity detection kit (Promega). Values are expressed as a mean concentration of $\mathrm{LDH}$ in the culture after $4 \mathrm{~h}$ of incubation. Data are mean values from three independent experiments. their autofluorescence, contained intracellular bacteria (data not shown).

\section{MFN1030 (hrpU-like operon disrupted mutant) phenotypes can be partially restored by expression of hrpU-like operon genes from SBW25}

MFN1030 is a mutant containing an insertion that disrupts the hrpU-like operon. This strategy of mutation can cause polar effects, i.e genetic modifications outside the targeted region. Thus, the phenotypes observed could be related to genes other than the hrpU-like operon. To check this possibility, the $r s c \mathrm{STU}$ genes of SBW25 (corresponding to the hrcSTU genes of MFN1032 affected by the hrpU-like operon disruption) were expressed from plasmid pBBR1MCS-5 in MFN1030. We choose to clone the rscSTU genes of SBW25 for complementation experiments because SBW25 genome is sequenced (in contrast to the $h r c U$ gene of MFN1032) and the rscRST genes present more than $90 \%$ of identity with the $h r c R S T$ genes of MFN1032. The phenotypes of the resulting strain, 

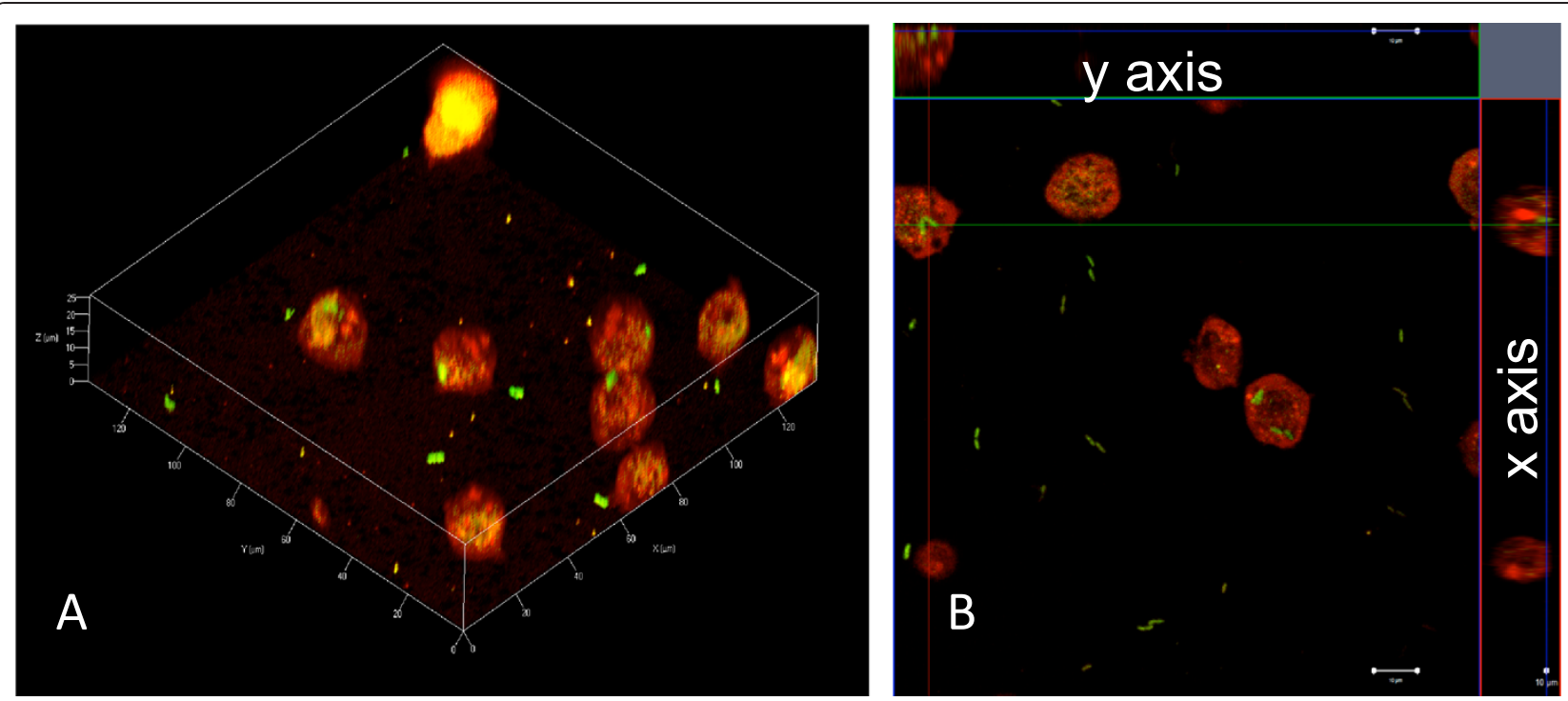

Figure 5 In vivo microscopy of macrophages infected by MFN1032. Confocal laser-scanning photography of Pseudomonas fluorescens MFN1032 with J774A.1 macrophages. J774A.1 macrophages grown in 24-well plates for 20h were infected with strains grown to an OD $580 \mathrm{~nm}$ of 1.0-1.5 (MOI of 10). Cytotoxicity was followed over a 10 min period by in vivo microscopy. The dead macrophages were red (by EtBr entry) and MFN1032 expressing GFP were green. A: Representative photography of a 3D modelisation of 17 z stack images of $1 \mu \mathrm{m}$. B: Representative orthographic representation of $1 \mu \mathrm{m}$ thick layer. The cell at the crossing of the red and green lines in the $z$ stack has been submitted to a stack in the $x$ and $y$ axis.

MFN1030-pBBR-rscSTU, are summarised in Table 2 (Results are means of at least three independent experiments). D. discoideum growth inhibition and cHA were restored in MFN1030-pBBR-rscSTU, with levels similar to those characteristic of wild type MFN1032. Macrophages lysis was partly restored in MFN1030-pBBR-rscSTU with a level corresponding to half of that of the wild type. Introduction of parental plasmid pBBR1MCS-5 in MFN1030 (MFN1030-pBBR1MC-5 strain) did not modify MFN1030 phenotypes.

\section{Discussion}

cHA seems dependent on strain origin and not only on T3SS basal part homology

All clinical P. fluorescens strains had cHA while environmental strains of Pseudomonas did not. Nevertheless, hrpU-like operons of SBW25, MF37 (environmental strains) and MFN1032 are highly homologous (more than $90 \%$ identity for the HrcR protein) [15]. This was confirmed by complementation of MFN1030 by the SBW25 genes. Even if hrpU-like operon genes are essential to the cHA of MFN1032, as demonstrated by MFN1030 mutant and complementation results, other factors that depend on the origin of the strain, like the T3SS upper part components or the T3SS effectors, are necessary for red blood cell lysis.

In C7R12 and SBW25 the functionality or mechanism of T3SS are not fully understood. On the contrary, P. syringae DC3000 has a functional T3SS with HrpZ as a translocation protein. In our conditions, T3SS of this phytopathogen was not able to induce cHA. This result confirms the inability of HrpZ to cause RBC lysis as described by Lee [31]. Moreover, none of the clinical strains induced HR on tobacco leaves, while C7R12 did. This suggests that the hrpUlike operons have a function in the hemolytic $P$. fluorescens clinical strains different from that in the biocontrol and phytopathogenic strains, which are able to induce T3SS mediated HR. These findings are in concordance with those of Mavrodi et al. who demonstrated the presence of stable divergent lineages of T3SS in Pseudomonas fluorescens strains [23].

Table 2 Phenotypes of MFN1032, MFN1030, MFN1030-pBBR-rscSTU and MFN1030-pBBR1MCS-5

\begin{tabular}{|c|c|c|c|c|}
\hline \multirow[t]{2}{*}{ Phenotypes } & \multicolumn{4}{|c|}{ Strains } \\
\hline & MFN1032 & MFN1030 & MFN1030-pBBR-rscSTU & MFN1030-pBBR1MCS-5 \\
\hline Cell-associated hemolytic activity $\left(\% \mathrm{cHA}\right.$ at $\left.28^{\circ} \mathrm{C}\right)$ & $69 \pm 10$ & $9 \pm 7$ & $69 \pm 3$ & $12 \pm 4$ \\
\hline D. discoideum growth inhibition (\%) & 100 & $11 \pm 3$ & 100 & $9 \pm 2$ \\
\hline Macrophages lysis (\% LDH release) & $40 \pm 3$ & 0 & $24 \pm 2$ & 0 \\
\hline
\end{tabular}


$P$. fluorescens clinical strains inhibit $D$. discoideum growth

$D$. discoideum growth inhibition is not a common feature in this species and was rarely found in P. fluorescens environmental strains, even if our panel is too low to be representative. The majority of environmental $P$. aeruginosa isolates have functional T3SSs with toxins that facilitate killing amoebae, their natural predators. Their T3SSs may have evolved for this purpose and broad conservation of targeted substrates across eukaryotic organisms resulted in a system active against human cells [32]. In $P$. fluorescens, the T3SS distribution is not homogenous. hrpU-like operons were absent from Pf0-1 and Pf5 but were present in numerous other rhizospheric strains [22,24], which leads us to believe that this mechanism of resistance to $D$. discoideum predation are not essential to P.fluorescens survival. However, the natural niches of $P$. fluorescens and $P$. aeruginosa are mainly the same, and bacteria are exposed to the same predation by amoebae. It should be noted that this it is, to our knowledge, the first report of $P$. fluorescens strains virulence towards amoebae.

\section{D. discoideum growth inhibition by MFN1032 seems positively controlled by the GacS/GacA system and involves the hrpU-like operon}

An interesting result was the loss of MFN1032 virulence towards $D$. discoideum in gacA and in hrpU-like operon mutants. Involvement of $\mathrm{GacS} / \mathrm{GacA}$ in growth inhibition of $D$. discoideum has been reported in a strain of $P$. entomophila, a soil bacterium with cyclolipopeptide production. P. entomophila gacA mutant is avirulent but CLPs and T3SS were not involved in virulence [33]. In $P$. aeruginosa full virulence requires T3SS and quorum sensing molecules (under GacS/GacA control) [18,20]. Again, these results underline the similarity of mechanisms with $P$. aeruginosa, despite the phylogenetic distance between the T3SS basal parts of these two species.

\section{Macrophage necrosis required the hrpU-like operon and is independent of the GacS/GacA system}

MFN1032 was able to provoke macrophage lysis in our conditions, but it was only half has effective as the CHA strain, a highly pathogenic $P$. aeruginosa strain. Macrophages lysis was not fully restored in the complemented strain, MFN1030-pBBR-rscSTU. That could be the consequence of the expression of rscSTU genes from a plasmid, under Plac promotor control, without their own upstream regulatory sequences. As with the CHA strain, necrosis was rapid (less than 10 minutes) for some macrophages. All dead macrophages contained bacteria. We hypothesize that bacterial internalisation by phagocytosis activity is a signal for an induction of virulence factor secretion. This rapid necrosis required hrpU-like operon and was independent of the GacS/GacA two- component system. These dependencies suggest that this mechanism is different from $D$. discoideum growth inhibition and similar to cHA activity. This was confirmed by the results in DC3000 which was unable to lyse macrophages and partially able to resist $D$. discoideum predation but lacking in $\mathrm{cHA}$. The mechanism of DC3000 virulence towards $D$. discoideum is to our knowledge unknown. Some literature suggests that this activity could be due to the action of biosurfactants produced by this strain [34].

\section{Conclusions}

MFN1032 is able to induce macrophage and red blood cell lysis and to prevent $D$. discoideum predation. In these three processes, hrpU-like operon is required but GacA/GacS positive regulation concerns only the $D$. discoideum model. Our findings establish a link between the T3SS and virulence of MFN1032 against eukaryotic cells. This study also underlines the high heterogeneity of the Pseudomonas according to their origin. The hypothesis of virulence acquisition towards human cells by a stochastic evolution of an ancestral mechanism dedicated to natural predator, such as amoebae, cannot explain all our results. We suggest that a major evolution of upper T3SS compounds or T3SS toxins, despite the conservation of the T3SS basal part, could be at the origin of MFN1032 virulence. This work must be extended to a larger representative panel of Pseudomonas fluorescens strains to confirm this hypothesis.

\section{Methods}

\section{Cell associated hemolytic activity assay (cHA)}

The cHA assay was done essentially as described by Dacheux [16]. Sheep red blood cells (RBC), obtained from Eurobio (France), were washed three times in PBS $\left(\mathrm{pH} 7.2,0.8 \% \mathrm{NaCl}, 0.02 \% \mathrm{KCl}, 0.17 \% \mathrm{Na}_{2} \mathrm{HPO}_{4}, 0.8 \%\right.$ $\mathrm{KH}_{2} \mathrm{PO}_{4}$ ) and resuspended in RPMI-1640 medium without $\mathrm{pH}$ indicator (Sigma) at a density of $5 \times 10^{8} \mathrm{RBC}$ $\mathrm{mL}^{-1}$ at $4^{\circ} \mathrm{C}$. The bacteria were grown in $\mathrm{LB}$ to an $\mathrm{OD}_{580 \mathrm{~nm}}$ of $0.7-1.5$, centrifuged and resuspended in RPMI-1640 at $5 \times 10^{8}$ bacteria.mL ${ }^{-1}$. Hemolysis assays were started by mixing $100 \mu \mathrm{L}$ of $\mathrm{RBC}$ and $100 \mu \mathrm{L}$ of bacteria, which were then centrifuged at $400 \mathrm{~g}$ for 10 minutes and incubated at $37^{\circ} \mathrm{C}$ for $1 \mathrm{~h}$. The release of hemoglobin was measured at $540 \mathrm{~nm}$, after centrifugation, in $100 \mu \mathrm{L}$ of cell supernatant.

The percentage (\%) of total lysis was calculated as follows: $\%=[(\mathrm{X}-\mathrm{B}) /(\mathrm{T}-\mathrm{B})] \times 100$, where $\mathrm{B}$ (baseline), a negative control, corresponds to $\mathrm{RBC}$ incubated with $100 \mu \mathrm{L}$ of RPMI-1640, and T, a positive control, corresponds to total RBC lysis, obtained by incubating cells with $0.1 \%$ SDS. $\mathrm{X}$ is the OD value of the analysed sample. 


\section{Plant Hypersensivity Response (HR) assay}

Plant HR assay was done essentially as described by Guo [35]. Bacterial strains grown on King $\mathrm{B}$ plates were resuspended at $1 \times 10^{8}$ cell. $\mathrm{mL}^{-1}$ in $5 \mathrm{mM}$ MES (Morpholineethane-sulfonic acid) $\mathrm{pH}$ 5.6. Each bacterial strain tested was infiltrated in Nicotiana tabacum cv. Xanthi. HR were recorded after 24 to $48 \mathrm{~h}$.

\section{Dictyostelium discoideum growth and plating assays}

This test was performed essentially as described by Carilla-Latorre [36]. Dictyostelium discoideum AX3 cells were grown axenically in HL5 medium pH 6.5 (Formadium) or in association with Klebsiella aerogenes on SM plates pH 6.5 (Formadium).

For the nutrient SM-plating assay, $P$. fluorescens strains, $P$. aeuginosa PA14 (positive control of virulence) and Klebsiella aerogenes (KA) (negative control of virulence) were grown overnight in LB. After washing in HL5, the tested bacteria were resuspended with HL5 to an optical density of 1 at $580 \mathrm{~nm}\left(1 \mathrm{OD}_{580 \mathrm{~nm}}\right)$ and KA was adjusted to $0.5 \mathrm{OD}_{580 \mathrm{~nm}}$.

$300 \mu \mathrm{L}$ of KA and $15 \mu \mathrm{l}$ of Pseudomonas (ratio 10\%) were plated in SM-agar plates with approximately 100 D. discoideum cells. The plates were maintained at $22^{\circ} \mathrm{C}$ for 5 days.

KA count were realized after incubation of $300 \mu \mathrm{L}$ of KA with or without $15 \mu \mathrm{L}$ of MFN1032, MFN1030 or $\mathrm{V} 1$ (ratio $10 \%$ ) in $\mathrm{SM}$ at $22^{\circ} \mathrm{C}$ for 5 days. Serial dilutions were plated on Hektoen enteric agar (bioMerieux) at $37^{\circ} \mathrm{C}$ to select $\mathrm{KA}$.

For some assay, $150 \mu \mathrm{L}$ of MFN1032, MFN1030, V1 $\left(0.5 \mathrm{OD}_{580 \mathrm{~nm}}\right)$ or $300 \mu \mathrm{L}$ of $\mathrm{KA}\left(\mathrm{OD}_{580 \mathrm{~nm}}\right)$ were plated in SM-agar plates and $2 \mu \mathrm{L}$ of serial dilution of $D$. discoideum culture (respectively 1000,100, 10 or $1 \mathrm{D}$. discoideum per $\mu \mathrm{L}$ ) were spotted on the bacterial layer. The plates were maintained at $22^{\circ} \mathrm{C}$ for 2 days.

\section{Cell culture and infection conditions}

Macrophage cell line J774A.1 was grown in Dulbecco's modified Eagle Minimal Essential Medium (DMEM) (Lonza) containing $10 \%$ foetal calf serum (FCS) supplemented with $2 \mathrm{mM} \mathrm{L}$-glutamine, $100 \mu \mathrm{g} \cdot \mathrm{mL}^{-1}$ penicillin, $100 \mu \mathrm{g} . \mathrm{mL}^{-1}$ streptomycin and $2 \mathrm{mM}$ pyruvic acid. The cells were seeded $20 \mathrm{~h}$ before infection in 24-well culture plates at $3 \times 10^{5}$ cells per well. Bacterial strains were grown overnight in $\mathrm{LB}(\mathrm{NaCl} 5 \mathrm{~g} / \mathrm{l})$, diluted to 0.08 $\mathrm{OD}_{580 \mathrm{~nm}}$ and grown for approximately $4 \mathrm{~h}$ more for $P$. fluorescens and $2 \mathrm{~h}$ more for $P$. aeruginosa to an $\mathrm{OD}_{580 \mathrm{~nm}}$ between 1.0 and 1.5 .

For the cytotoxicity assay, one day before infection, the macrophages were antibiotic starved. The macrophages were infected with bacteria resuspended in $1 \mathrm{ml}$ of DMEM in order to give an MOI (multiplicity of infection) of $5\left(15 \times 10^{5}\right.$ bacteria.mL $\left.{ }^{-1}\right)$. After 4 hours of incubation under controlled atmosphere $\left(37^{\circ} \mathrm{C}, 5 \%\right.$ $\mathrm{CO}_{2}$ ), lactate dehydrogenase ( $\left.\mathrm{LDH}\right)$ present in the supernatant was measured in each well using cytotox $96^{\circledR}$ enzymatic assay (Promega). LDH is a stable cytosolic enzyme released by eukaryotic cells and is an overall indicator of necrosis. J774A.1 cells exposed to Triton $\mathrm{X} 100(0.9 \%)$ were used as a control of total release (100\% LDH release). The background level (0\% LDH release) was determined with serum free culture medium. The percentage (\%) of total lysis was calculated as follows: $\%=[(\mathrm{X}-\mathrm{B}) /(\mathrm{T}-\mathrm{B})] \times 100$, where $\mathrm{B}$ (baseline) is a negative control and $\mathrm{T}$ (total lysis) is a positive control. X is the $\mathrm{OD}_{490 \mathrm{~nm}}$ value of the analysed sample.

For in vitro microscopy, macrophages were infected with MFN1032 strain expressing Green Fluorescent Protein (pSMCP2.1 carrying $g f p$ gene), resuspended in $1 \mathrm{ml}$ of DMEM, in order to give an MOI of 10 and incubated for $10 \mathrm{~min}$ at $37^{\circ} \mathrm{C}, 5 \% \mathrm{CO}_{2}$ [37]. The medium was supplemented with $500 \mathrm{ng} \cdot \mathrm{mL}^{-1} \mathrm{EtBr}$, which enters only into dead cells. Infection was followed using an inverted Zeiss (LSM 710) confocal laser-scanning microscope with an oil immersion 63X/1.40 plan-apochromatic objective. Plates were excited with a wavelength of $488 \mathrm{~nm}$ for GFP (emission: 493-539 nm) and $514 \mathrm{~nm}$ for $\mathrm{EtBr}$ (emission 589-797). 3D modelisation and orthographic representation were processed using Zen ${ }^{\circledR} 2009$ (Zeiss) software and a Kernel of 3x3 (x, y) was applied.

\section{Expression of $r s c$ STU genes from SBW25 in MFN1030 (MFN1032 hrpU-like operon disrupted mutant)}

SBW25 was used for PCR amplification of rscSTU genes. PCR primers, rscSSBW25 (5'-ATGGAACCAAT CGATCTGTTC-3') and SBWrscU (5'-TCAGTGCCGT TCAAGCTC-3'), synthesized by Eurogentec (Angers, France), were designed to amplify $r s c \mathrm{STU}$ genes (2156 bp), a region of the rsp cluster I of SBW25, corresponding to genes $h r c \mathrm{STU}$ affected by hrpU-like operon disruption in MFN1030.

PCR was carried out in a $50 \mu \mathrm{L}$ reaction volume, in a MJ mini thermal cycler (Bio-rad laboratories incorporation, USA). Reaction mixture contained $4 \mu \mathrm{L}$ DNA, 0.5 $\mu \mathrm{L}$ Taq phusion polymerase (Biolabs, new England), 10 $\mu \mathrm{L}$ corresponding buffer, $4 \mu \mathrm{L}$ primers $(20 \mu \mathrm{M})$ and $4 \mu \mathrm{L}$ deoxyribonucleoside triphosphate $(2.5 \mathrm{mM})$. After initial denaturation for 10 seconds at $98^{\circ} \mathrm{C}$, the reaction mixture was subjected to 30 cycles of 30 seconds at $98^{\circ} \mathrm{C}, 30$ seconds at $49^{\circ} \mathrm{C}$ and 1 minute at $72^{\circ} \mathrm{C}$, followed by a final 5 minutes extension at $75^{\circ} \mathrm{C}$. Aliquots $(10 \mu \mathrm{L})$ of the PCR products were analyzed by electrophoresis in $1 \%$ agarose gels, stained with ethidium bromide and photographed under UV illumination.

PCR product was cloned with the pBBR1MCS-5 $(4,8 \mathrm{~KB})$ digested by Sma I [38]. This construction, pBBR-rscSTU $(6,9 \mathrm{~kb})$, was then introduced into 
Escherichia coli DH5 $\mathrm{a}$ mor cells by electroporation. White colonies were selected for their resistance to gentamycin $(20 \mu \mathrm{g} / \mathrm{mL})$. Plasmids were isolated using the QIAprep Spin Miniprep Kit (Qiagen), checked by sequencing (beckman coulter genomics, Germany) and then transferred into the Escherichia coli conjugative strain S17.1.

MFN1030 (tetracyclin resistant) cells were conjugated with S17.1 cells carrying the pBBR-rscSTU plasmid and strains were selected for their resistance to tetracycline $\left(20 \mu \mathrm{g} \cdot \mathrm{mL}^{-1}\right)$ and gentamycin $\left(20 \mu \mathrm{g} \cdot \mathrm{mL}^{-1}\right)$. The resulting strain was called MFN1030-pBBR-rscSTU.

\section{Bacterial strains and culture conditions}

The origin of each strain tested in this study can be found in Table 1. The bacteria were cultured in Luria Bertani medium (LB) at optimum growth temperatures, i.e. $28^{\circ} \mathrm{C}$ for $P$. fluorescens (for MF37 origin, see [39]) and $P$. syringae $\mathrm{DC} 3000[40], 37^{\circ} \mathrm{C}$ for $P$. aeruginosa CHA or PA14 [41,42] and Klesiella aerogenes [43], with shaking at $180 \mathrm{rpm}$. When necessary, $80 \mu \mathrm{g} / \mathrm{mL}$ Xgal, 20 $\mu \mathrm{g} / \mathrm{mL}$ tetracycline, $20 \mu \mathrm{g} / \mathrm{mL}$ gentamycin or $30 \mu \mathrm{g} / \mathrm{mL}$ kanamycin were added. The bacterial density was determined by measuring optical density (OD) at $580 \mathrm{~nm}$ (Spectronic Unicam spectrophotometer).

\section{Authors' contributions}

DS carried out the assays with VD help and participated in the design of the manuscript. AM designed the study, wrote the manuscript and analyzed most of the data. LM and MH were involved in the in vitro microscopy assays and analysis. XL helped to design and writes the manuscript. $\mathrm{NO}$ and MF were involved in designing the study. All authors read and approved the final manuscript.

\section{Acknowledgements}

This study was supported by grant from the Région Haute-Normandie. We thank INRA UR1282, infectiologie animale et santé publique, groupe "signalisation, portage et virulence bactérienne" for help with macrophage J774A.1 infection. We thank Azeddine Driouich and Sophie Bernard, Laboratoire de Glycobiologie et Matrice Extracellulaire Végétale (GlycoMEV), EA 4358, Université de Rouen, for help in tobacco assay. We thank Magalie Barreau for technical assistance and Christine Farmer and Victor Norris for linguistic support.

Received: 9 March 2012 Accepted: 25 September 2012 Published: 29 September 2012

\section{References}

1. Bossis E, Lemanceau P, Latour X, Gardan L: The taxonomy of Pseudomonas fluorescens and Pseudomonas putida: current status and need for revision. B Agron Sustain Dev 2000, 20:51-63.

2. Stanier RY, Palleroni NJ, Doudoroff M: The aerobic pseudomonads: a taxonmic study. J Gen Microbiol 1996, 43:159-271.

3. Haas D, Keel C, Reimmann C: Signal transduction in plant-beneficial rhizobacteria with biocontrol properties. Antonie Van Leeuwenhoek 2002, 81(1-4):385-395

4. Spiers AJ, Buckling A, Rainey PB: The causes of Pseudomonas diversity. Microbiology 2000, 146(Pt 10):2345-2350.

5. Weller DM: Pseudomonas biocontrol agents of soilborne pathogens: looking back over 30 years. Phytopathology 2007, 97(2):250-256.

6. Bodilis J, Calbrix R, Guerillon J, Merieau A, Pawlak B, Orange N, Barray S: Phylogenetic relationships between environmental and clinical isolates of Pseudomonas fluorescens and related species deduced from $16 \mathrm{~S}$ rRNA gene and OprF protein sequences. Syst Appl Microbiol 2004, 27(1):93-108.

7. Berg G, Eberl L, Hartmann A: The rhizosphere as a reservoir for opportunistic human pathogenic bacteria. Environ Microbiol 2005, 7(11):1673-1685.

8. Merieau A, Gügi B, Guespin-Michel JF, Orange N: Temperature regulation of lipase B. secretion by Pseudomonas fluorescens strain MFO. Appl Microbiol Biotechnol 1993, 39:104-109.

9. Rossignol G, Sperandio D, Guerillon J, Duclairoir Poc C, Soum-Soutera E, Orange N, Feuilloley MG, Merieau A: Phenotypic variation in the Pseudomonas fluorescens clinical strain MFN1032. Res Microbiol 2009, 160:337-344.

10. Donnarumma G, Buommino E, Fusco A, Paoletti I, Auricchio L, Tufano MA: Effect of temperature on the shift of Pseudomonas fluorescens from an environmental microorganism to a potential human pathogen. Int J Immunopathol Pharmacol 2010, 23(1):227-234.

11. Chapalain A, Rossignol G, Lesouhaitier O, Merieau A, Gruffaz C, Guerillon J, Meyer JM, Orange N, Feuilloley MG: Comparative study of 7 fluorescent pseudomonad clinical isolates. Can J Microbiol 2008, 54(1):19-27.

12. Madi A, Lakhdari O, Blottiere HM, Guyard-Nicodeme M, Le Roux K, Groboillot A, Svinareff P, Dore J, Orange N, Feuilloley MG, Connil N: The clinical Pseudomonas fluorescens MFN1032 strain exerts a cytotoxic effect on epithelial intestinal cells and induces Interleukin-8 via the AP-1 signaling pathway. BMC Microbiol 2010, 10:215.

13. Rossignol G, Merieau A, Guerillon J, Veron W, Lesouhaitier O, Feuilloley MG, Orange N: Involvement of a phospholipase $C$ in the hemolytic activity of a clinical strain of Pseudomonas fluorescens. BMC Microbiol 2008, 8:189.

14. Richard A, Rossignol G, Comet JP, Bernot G, Guespin-Michel J, Merieau A Boolean models of biosurfactants production in Pseudomonas fluorescens. PLoS One 2012, 7(1):e24651.

15. Sperandio D, Rossignol G, Guerillon J, Connil N, Orange N, Feuilloley MG Merieau A: Cell-associated hemolysis activity in the clinical strain of Pseudomonas fluorescens MFN1032. BMC Microbiol 2010, 10:124.

16. Dacheux D, Goure J, Chabert J, Usson Y, Attree I: Pore-forming activity of type III system-secreted proteins leads to oncosis of Pseudomonas aeruginosa-infected macrophages. Mol Microbiol 2001, 40(1):76-85.

17. Cosson P, Soldati T: Eat, kill or die: when amoeba meets bacteria. Curr Opin Microbiol 2008, 11(3):271-276.

18. Alibaud L, Kohler T, Coudray A, Prigent-Combaret C, Bergeret E, Perrin J, Benghezal M, Reimmann C, Gauthier Y, van Delden C, Attree I, Fauvarque $\mathrm{MO}$, Cosson P: Pseudomonas aeruginosa virulence genes identified in a Dictyostelium host model. Cell Microbiol 2008, 10(3):729-740.

19. Pukatzki S, Kessin RH, Mekalanos JJ: The human pathogen Pseudomonas aeruginosa utilizes conserved virulence pathways to infect the social amoeba Dictyostelium discoideum. Proc Natl Acad Sci USA 2002, 99(5):3159-3164.

20. Cosson P, Zulianello L, Join-Lambert O, Faurisson F, Gebbie L, Benghezal M, Van Delden C, Curty LK, Kohler T: Pseudomonas aeruginosa virulence analyzed in a Dictyostelium discoideum host system. J Bacteriol 2002, 184(11):3027-3033.

21. Loper JE, Kobayashi DY, Paulsen IT: The Genomic Sequence of Pseudomonas fluorescens Pf-5: Insights Into Biological Control. Phytopathology 2007, 97(2):233-238.

22. Ma Q, Zhai Y, Schneider JC, Ramseier TM, Saier MH Jr: Protein secretion systems of Pseudomonas aeruginosa and P. fluorescens. Biochim Biophys Acta 2003, 1611(1-2):223-233.

23. Mavrodi DV, Joe A, Mavrodi OV, Hassan KA, Weller DM, Paulsen IT, Loper JE, Alfano JR, Thomashow LS: Structural and Functional Analysis of the Type III Secretion System from Pseudomonas fluorescens Q8r1-96. J Bacteriol 2011, 193(1):177-189.

24. Mazurier S, Siblot S, Mougel C, Lemanceau P: Distribution and diversity of type III secretion system-like genes in saprophytic and phytopathogenic fluorecent Pseudomonas. FEMS Microbiol Ecol 2004, 49:455-467.

25. Preston GM, Bertrand N, Rainey PB: Type III secretion in plant growthpromoting Pseudomonas fluorescens SBW25. Mol Microbiol 2001, 41(5):999-1014.

26. Rezzonico F, Binder C, Defago G, Moenne-Loccoz Y: The type III secretion system of biocontrol Pseudomonas fluorescens KD targets the phytopathogenic Chromista Pythium ultimum and promotes cucumber protection. Mol Plant Microbe Interact 2005, 18(9):991-1001. 
27. Mirleau P, Delorme S, Philippot L, Meyer J, Mazurier S, Lemanceau P: Fitness in soil and rhizosphere of Pseudomonas fluorescens C7R12 compared with a C7R12 mutant affected in pyoverdine synthesis and uptake. FEMS Microbiol Ecol 2000, 34(1):35-44.

28. Duclairoir-Poc C, Ngoya S, Groboillot A, Bodilis J, Taupin L, Merieau A, Feuilloley MG, Orange N: Study of the influence of growth temperature on cyclolipopeptides production in environmental strains of Pseudomonas fluorescens. J Bacteriol Parasitol 2011, S1:002.

29. Polack B, Dacheux D, Delic-Attree I, Toussaint B, Vignais PM: Role of manganese superoxide dismutase in a mucoid isolate of Pseudomonas aeruginosa: adaptation to oxidative stress. Infect Immun 1996, 64(6):2216-2219

30. Filopon D, Merieau A, Bernot G, Comet JP, Leberre R, Guery B, Polack B, Guespin-Michel J: Epigenetic acquisition of inducibility of type III cytotoxicity in P. aeruginosa. BMC Bioinforma 2006, 7:272.

31. Lee J, Klusener B, Tsiamis G, Stevens C, Neyt C, Tampakaki AP, Panopoulos NJ, Noller J, Weiler EW, Cornelis GR, Mansfield JW, Nürnberger T: HrpZ (Psph) from the plant pathogen Pseudomonas syringae pv. phaseolicola binds to lipid bilayers and forms an ion-conducting pore in vitro. Proc Natl Acad Sci USA 2001, 98(1):289-294.

32. Hauser AR: The type III secretion system of Pseudomonas aeruginosa: infection by injection. Nat Rev Microbiol 2009, 7(9):654-665.

33. Vallet-Gely I, Novikov A, Augusto L, Liehl P, Bolbach G, Pechy-Tarr M, Cosson $P$, Keel C, Caroff M, Lemaitre B: Association of hemolytic activity of Pseudomonas entomophila, a versatile soil bacterium, with cyclic lipopeptide production. Appl Environ Microbiol 2010, 76(3):910-921.

34. Berti AD, Greve NJ, Christensen QH, Thomas MG: Identification of a biosynthetic gene cluster and the six associated lipopeptides involved in swarming motility of Pseudomonas syringae pv. tomato DC3000. J Bacteriol 2007, 189(17):6312-6323.

35. Guo M, Tian F, Wamboldt Y, Alfano JR: The majority of the type III effector inventory of Pseudomonas syringae pv. tomato DC3000 can suppress plant immunity. Mol Plant Microbe Interact 2009, 22(9):1069-1080.

36. Carilla-Latorre S, Calvo-Garrido J, Bloomfield G, Skelton J, Kay RR, Ivens A, Martinez JL, Escalante R: Dictyostelium transcriptional responses to Pseudomonas aeruginosa: common and specific effects from PAO1 and PA14 strains. BMC Microbiol 2008, 8:109.

37. Bloemberg GV, O'Toole GA, Lugtenberg BJ, Kolter R: Green fluorescent protein as a marker for Pseudomonas spp. Appl Environ Microbiol 1997, 63(11):4543-4551.

38. Kovach ME, Phillips RW, Elzer PH, Roop RM 2nd, Peterson KM: pBBR1MCS: a broad-host-range cloning vector. Biotechniques 1994, 16(5):800-802.

39. Burini JF, Gugi B, Merieau A, Guespin-Michel JF: Lipase and acidic phosphatase from the psychrotrophic bacterium Pseudomonas fluorescens: two enzymes whose synthesis is regulated by the growth temperature. FEMS Microbiol Lett 1994, 122(1-2):13-18.

40. Cuppels DA: Generation and Characterization of Tn5 Insertion Mutations in Pseudomonas syringae pv. tomato. Appl Environ Microbiol 1986, 51(2):323-327

41. Toussaint B, Delic-Attree I, Vignais PM: Pseudomonas aeruginosa contains an IHF-like protein that binds to the algD promoter. Biochem Biophys Res Commun 1993, 196(1):416-421.

42. Tan MW, Rahme LG, Sternberg JA, Tompkins RG, Ausubel FM: Pseudomonas aeruginosa killing of Caenorhabditis elegans used to identify $P$. aeruginosa virulence factors. Proc Natl Acad Sci USA 1999, 96(5):2408-2413.

43. Dagley S, Dawes EA, Morrison GA: Inhibition of growth of Aerobacter aerogenes; the mode of action of phenols, alcohols, acetone, and ethyl acetate. J Bacterio/ 1950, 60(4):369-379.

doi:10.1186/1471-2180-12-223

Cite this article as: Sperandio et al: Virulence of the Pseudomonas fluorescens clinical strain MFN1032 towards Dictyostelium discoideum and macrophages in relation with type III secretion system. BMC Microbiology 2012 12:223.

\section{Submit your next manuscript to BioMed Central and take full advantage of:}

- Convenient online submission

- Thorough peer review

- No space constraints or color figure charges

- Immediate publication on acceptance

- Inclusion in PubMed, CAS, Scopus and Google Scholar

- Research which is freely available for redistribution

Submit your manuscript at www.biomedcentral.com/submit
C Biomed Central 